to the late Prof. G. Denigés ; Prof. K. M. G. Siegbahn, director of the Nobel Institute for Physics, Stockholm, in succession to Sir C. V. Raman, elected foreign associate; and Prof. Arne Westgren, professor of chemistry, University of Stockholm, in succession to the Rev. P. Teilhard de Chardin, elected non-resident member.

\section{Progress in Fat Chemistry during 1900-50}

In the third Leverhulme Memorial Lecture to the Society of Chemical Industry (Chemistry and Industry, 154 ; 1951), Prof. T. P. Hilditch, Campbell Brown professor of industrial chemistry in the University of Liverpool, dealt with progress in fat chemistry during the period 1900-50, pointing out that this owed much to the interplay between industrial advances and academic research. Progress has been very noteworthy in this period. At the present time the structures of some fifty naturally occurring unsaturated acids, and the exact proportions of each of the mixed fatty acids of all fatty oils and natural fats used industrially, are known. Prof. Hilditch referred to the importance of the process of hardening liquid oils by hydrogenation as one of the earliest largescale applications of a catalytic process. The different behaviour of hardened fats in soap-making as compared with natural fats, which was discovered empirically, has a seientific foundation. The relation between the fat in vegetable seeds or animal tissues and the natural species, and the mode of assembly of fatty acids into triglycerides, were dealt with in some detail in the Lecture, and these show many interesting features. Human milk fat is more akin to soft margarine than to cow butter fat. The question of rancidity in fats has received attention. Prof. Hilditch mentioned that processes used in the laboratory, such as the separation by solvents, might later on find technical applications. The Lecture gave a detailed and balanced picture of modern knowledge of oils and fats which should be of much interest both to chemists and biologists.

\section{Safety in the Use of Explosives in Coal Mines}

Following the explosion at the Whitehaven William Colliery in 1947, the Chief Inspector of Mines, who conducted the formal inquiry, made certain general and specific recommendations with regard to shot-firing. These recommendations involved further amendments to the Explosives in Coal Mines Order, and the Minister of Fuel and Power decided that the whole field of safety in relation to the use of explosives in coal mines should be reviewed. A committee, representing all sides of the industry, with Mr. A. M. Bryan, chief inspector of mines, as chairman, was accordingly set up by the Minister in January 1948, and its report was published last year (pp. 52 ; London: H.M. Stationery Office, 1950 ; $1 s .6 d$. net). The committee's deliberations are described under two headings, general considerations and a review of the provisions of the Order. A number of recommendations of a general character are set out in summarized form in an appendix. A second appendix outlines a proposed new Explosives in Coal Mines Order, and a third lists some of the points which it is suggested should be covered in a 'Code of Good Practice' to be issued to the coal mine industry. The committee, though its terms of reference were confined to consideration of the use of explosives in coal mines, offers the suggestion that the different conditions and methods of work in mines of stratified iron-stone, shale and fireclay make it desirable to draw up separate Explosives Orders for these classes of mines.

\section{International Bulletin of Bacteriological Nomenclature and Taxonomy}

THE organization of the International Committee on Bacteriological Nomenclature, established at the first International Congress for Microbiology at Paris in 1930, was developed at subsequent meetings and, at the Congress held in Rio de Janeiro in 1950, the duties of the International Committe and of the Judicial Commission selected from its members were more fully defined. An editorial board was created, with the function of publishing details of the official actions of the Congresses, the Committee and the Commission. For this purpose, an International Bulletin of Bacteriological Nomenclature and Taxonomy is to be published quarterly (annual subscription 2 dollars, payable to the International Microbiological Fund and sent to Prof. R. E. Buchanan, Curtiss Hall, Iowa State University, Ames, Iowa). It is hoped that this Bulletin will contribute to the stabilization of nomenclature by serving as a medium for discussion between those concerned in naming and classifying bacteria. It will include amendments to the Bacteriological Code of Nomenclature and reports of the various subcommittees set up to study problems of taxonomy of certain groups of micro-organisms. An important function of the Bulletin will be to record the official opinions of the Judicial Commission concerning problems of nomenclature. In the first number of the Bulletin, which has just been published, two opinions are issued and details are given of forty-five further problems upon which an opinion has been requested. The Commission will prepare a preliminary statement about each of these problems and invites comments and suggestions from interested persons. Papers reporting the results of scientific experiment will not be published in the Bulletin. The editorial board consists of Prof. R. E. Buchanan of Towa (chairman of the Commission) and the permanent secretaries, Prof. R. S. Breed, 6 Sunset Drive, Geneva, N.Y., and Dr. S. T. Cowan, Central Public Health Laboratory, Colindale Avenue, London, N.W.9.

\section{Corrosion Group of the Society of Chemical Industry}

THE Council of the Society of Chemical Industry has approved the formation of a new subject group of the Society, to be called the "Corrosion Group". This is intended to fill the need for a scientific society in Great Britain to deal with the study of corrosion and its prevention, which is now of recognized technical and economic importance in many industries. The inaugural meeting of the Group, of which the chairman-designate is Dr. W. H. J. Vernon, was held on May 17 at the Royal Institution, when the president of the Society of Chemical Industry, Mr. Stanley Robson, presided over a large audience. The inaugural address was given by Dr. U. R. Evans, reader in the science of metallic corrosion in the University of Cambridge. Taking as his title "The Corrosion Situation, Past, Present and Future", Dr. Evans described corrosion as one of the major problems of the day, the solution of which would affect the chances of maintaining a high standard of living. Shortage of metals must be met not merely by increasing supply but also by reducing wastage, and in this field the trained worker in the field of corrosion has an important part to play. There is a 